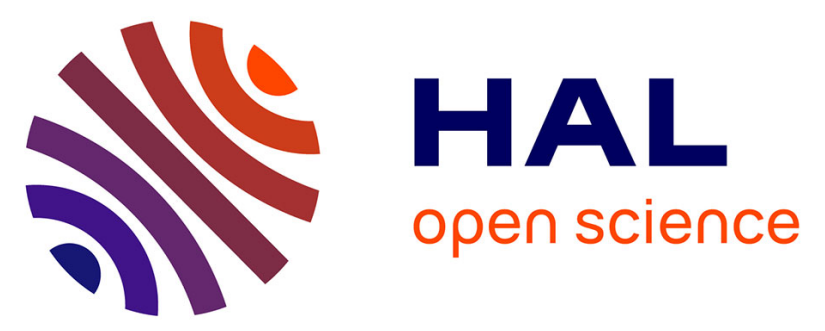

\title{
Mineralogical and Physico-Chemical Characterizations of Ferruginous Beidellite-Rich Clay from Agadir Basin (Morocco)
}

Lahcen Bouna, Benaïssa Rhouta, Lahcen Daoudi, Francis Maury, M’barek Amjoud, François Senocq, Marie-Christine Lafont, Amane Jada, A. Aït

Aghzzaf

\section{To cite this version:}

Lahcen Bouna, Benaïssa Rhouta, Lahcen Daoudi, Francis Maury, M'barek Amjoud, et al.. Mineralogical and Physico-Chemical Characterizations of Ferruginous Beidellite-Rich Clay from Agadir Basin (Morocco). Clays and Clay Minerals, 2012, vol. 60 ( $\mathrm{n}^{\circ}$ 3), pp. 278-290. 10.1346/CCMN.2012.0600305 . hal-01172393

\section{HAL Id: hal-01172393 \\ https://hal.science/hal-01172393}

Submitted on 7 Jul 2015

HAL is a multi-disciplinary open access archive for the deposit and dissemination of scientific research documents, whether they are published or not. The documents may come from teaching and research institutions in France or abroad, or from public or private research centers.
L'archive ouverte pluridisciplinaire HAL, est destinée au dépôt et à la diffusion de documents scientifiques de niveau recherche, publiés ou non, émanant des établissements d'enseignement et de recherche français ou étrangers, des laboratoires publics ou privés. 


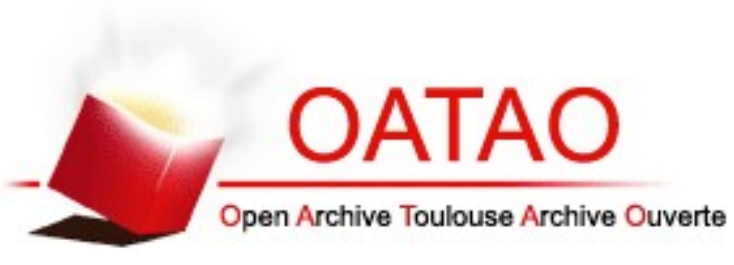

\section{Open Archive TOULOUSE Archive Ouverte}

OATAO is an open access repository that collects the work of Toulouse researchers and makes it freely available over the web where possible.

This is an author-deposited version published in : http://oatao.univ-toulouse.fr/ Eprints ID : 14098

To link to this article : DOI:10.1346/CCMN.2012.0600305

URL : $\underline{\text { http://dx.doi.org/10.1346/CCMN.2012.0600305 }}$

To cite this version : Bouna, Lahcen and Rhouta, Benaïssa and Daoudi, Lahcen and Maury, Francis and Amjoud, M'Barek and Senocq, François and Lafont, Marie-Christine and Jada, Amane and Aghzzaf, A. Ait Mineralogical and Physico-Chemical Characterizations of Ferruginous Beidellite-Rich Clay from Agadir Basin (Morocco). (2012) Clays and Clay Minerals, vol. 60 ( $\left.\mathrm{n}^{\circ} 3\right)$. pp. 278-290. ISSN 0009-8604

Any correspondance concerning this service should be sent to the repository administrator: staff-oatao@,listes-diff.inp-toulouse.fr 


\title{
MINERALOGICAL AND PHYSICO-CHEMICAL CHARACTERIZATIONS OF FERRUGINOUS BEIDELLITE-RICH CLAY FROM AGADIR BASIN (MOROCCO)
}

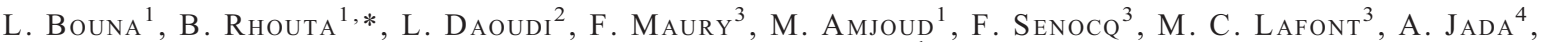 \\ And A. AÏT Aghzzaf ${ }^{1}$ \\ ${ }^{1}$ Laboratoire de Matière Condensée et Nanostructures (LMCN), Faculté des Sciences et Techniques Guéliz, Université Cadi \\ Ayyad, BP 549, Marrakech, Morocco \\ ${ }^{2}$ Laboratoire de Géosciences et Géoenvironnement, Faculté des Sciences et Techniques Guéliz, Université Cadi Ayyad, BP 549, \\ Marrakech, Morocco \\ ${ }^{3}$ CIRIMAT, Université de Toulouse, CNRS-UPS-INP, ENSIACET, 4 allée Emile Monso, BP 44362, 31030 Toulouse, cedex 4, \\ France \\ ${ }^{4}$ Institut de Sciences des Matériaux de Mulhouse (IS2M), LRC 7228 - CNRS, 15 rue Jean Starcky, BP 2488, 68057 Mulhouse \\ cedex, France
}

\begin{abstract}
The mechanism of formation of detrital, beidellite-rich clay occurring in the Agadir basin (Morocco) is well documented, but its detailed characterization is incomplete which limits its application. The aim of the present study was to provide further details of the mineralogical and physico-chemical characteristics of this clay. Bulk raw clay and its $\mathrm{Na}^{+}$-saturated, $<2 \mu \mathrm{m}$ fraction were characterized using chemical, structural, and thermal techniques. Measurements of induced streaming potential (e.g. particle charge) and of specific surface area and porous volume are reported. The raw clay contained carbonate and quartz as associated minerals along with phyllosilicates $(<2 \mu \mathrm{m}$ particle size). X-ray diffraction and scanning electron microscopy analyses showed that the $<2 \mu \mathrm{m}$ fraction was dominated by a dioctahedral smectite. Because dehydroxylation of this mineral occurred at $510^{\circ} \mathrm{C}$, and because it re-expanded in ethylene glycol after $\mathrm{Li}^{+}$-saturation followed by heating at $240^{\circ} \mathrm{C}$ for $24 \mathrm{~h}$, the mineral was shown to be a beidellite rather than montmorillonite. This assertion was further supported by ${ }^{27} \mathrm{Al}$ and ${ }^{29} \mathrm{Si}$ magic-angle spinning nuclear magnetic resonance spectra showing predominantly negative charges in the tetrahedral sheets due to notable Al-for-Si substitutions. The chemical composition of the $<2 \mu \mathrm{m}$ fraction showed an $\mathrm{Fe}_{2} \mathrm{O}_{3}$ content which was $\sim 7.52 \mathrm{wt}$. \% greater than those of other beidellite occurrences but not so much that it would be identified as a nontronite. The absence of stretching and bending absorption bands corresponding to characteristic $\left(\mathrm{Fe}_{2} \mathrm{OH}\right)$ units in mid-infrared spectra and their corresponding fundamental overtones or combination bands in near-infrared spectra supported this notion. The structural formula of the beidellite in the present study was determined to be $\left(\mathrm{Si}_{7.51} \mathrm{Al}_{0.49}\right)\left(\mathrm{Al}_{2.99} \mathrm{Fe}_{0.68} \mathrm{Mg}_{0.33}\right)$ $\left(\mathrm{Ca}_{0.03} \mathrm{Na}_{0.54} \mathrm{Mg}_{0.11}\right) \mathrm{O}_{20}(\mathrm{OH})_{4}$, having dioctahedral ferruginous characteristics with almost $60 \%$ of the negative charge found in tetrahedral sheets. The cation exchange capacity determined from the structural formula was $\sim 108 \mathrm{meq} / 100 \mathrm{~g}$. The specific surface area and total pore volume were $\sim 82.2 \mathrm{~m}^{2} / \mathrm{g}$ and $0.136 \mathrm{~cm}^{3} / \mathrm{g}$, respectively. Interestingly, a detrital rather than a hydrothermal-alteration origin, as reported for other beidellite occurrences, explains its natural abundance and emphasizes the great interest in it.
\end{abstract}

Key Words-Agadir Basin, Beidellite, Clay, Dioctahedral, Ferruginous, Greene-Kelly Test, Hofmann-Klemen Effect, Tetrahedral-octahedral Charge Magnitude.

\section{INTRODUCTION}

Smectites are easily modified and so interest continues in developing from them organic-clay hybrid materials (Lagaly et al., 2006), new inorganic heterostructures (Letaïef et al., 2006), polymer and biopolymer clay nanocomposites (Alexandre and Dubois, 2000; Darder et al., 2005), and other advanced materials for various applications, including adsorption, catalysis, sensors, optical devices, etc. (Ruiz-Hitzky et al., 2004). Montmorillonite, especially Wyoming dioctahedral

* E-mail address of corresponding author: rhoutab@yahoo.fr
Al-rich montmorillonite, is the most studied smectite in the world. Beidellite is arguably the most interesting member of the smectite family and is researched for its good acidic behavior (e.g. stronger acidity than montmorillonite) in heterogeneous catalytic reactions (Weir and Greene-Kelly, 1962). Because the use of beidellite as a heterogeneous catalyst requires very high phase purity and well controlled chemistry, several studies (Ewell and Insley, 1935; Kloprogge et al., 1999a, 1999b; Kloprogge, 2006, Plee and Fripiat, 1987, Schutz et al., 1987) have attempted to synthesize beidellite with high chemical purity and adjusted composition. Beidellite is a relatively rare clay mineral in nature (Post et al., 1997), found primarily in veins of hydrothermally altered igneous rocks (Nadeau et al., 1985) and often with associated hydrothermal clay minerals, including kaolin- 
ite, halloysite, dickite, nacrite, montmorillonite, rectorite, tarasovite-like clay, and mainly mixed-layer illitebeidellite (Post et al., 1997; Post and Borer, 2002). Because of the nature of their geological occurrence, beidellitic clay deposits are limited in extent and most of the classic localities are now, unfortunately, depleted (Nadeau et al., 1985). The name beidellite was given by Larsen and Wherry to a clay specimen from Beidell, Colorado, USA (Weir and Greene-Kelly, 1962; Kloprogge, 2006). The other best known and well characterized beidellite deposits are located in Unterrrupsroh, Germany (Nadeau et al., 1985) and Black Jack Mine, Idaho, USA (Weir and Greene-Kelly, 1962; Post et al., 1997; Post and Borer, 2002; Woessner, 1989).

A clay deposit from the Agadir basin (Morocco) has been reported (Daoudi et al., 2008), which appears to be rich in beidellite. The present study focuses mainly on the distribution and significance of this smectite, its detrital origin (see below) explaining its great abundance, and its large geographic extent. Both the raw clay and its $<2 \mu \mathrm{m}$ fraction were studied in order to determine their mineralogical, physico-chemical, textural, and structural properties. Knowledge of these properties is vital before considering the clay for use as a low-cost, natural starting material in the development of innovative clay-based materials.

\section{GEOLOGICAL SETTING AND CONTEXT}

The sample studied here was taken from the Taghazout locality in the western High Atlas basin
(Morocco) and, hence, it is designated 'TAG.' Stratigraphically, the sample came from the upper Cenomanian-lower Turonian sequences, located at Agadir coastal road, $20 \mathrm{~km}$ north of Agadir city (Figure 1). These sedimentary series are well exposed in the coastal cliffs and $>150$ m thick; the series consists of shell beds and interbedded silty, yellowish-green and dark-gray marls indicating a typical facies (Butt, 1982; Stamm and Thein, 1982). In the western High Atlas basin, evolution of the clay assemblage of the upper Cenomanian-Turonian sequences shows very significant geographical and stratigraphical variations (Daoudi and Deconninck, 1994). In the Agadir area, in the thicker and more developed Cretaceous series of the basin, the clay fraction is usually dominated by smectite with small amounts of illite and kaolinite. In the upper part of the series, the clay fraction is characterized by the disappearance of kaolinite and illite and by the development of smectite; the studied sample (TAG) was taken from this level.

The abundance of the smectite (Daoudi et al., 2008), and the fact that this abundance does not appear to be related to the depth of burial in the upper Cenomanian (Daoudi et al., 2010), suggests that the origin and evolution of the smectite were not controlled by postsedimentary processes. Smectite, which is considered common in open-sea environments and the origin of which is frequently attributed to authigenic and hydrothermal processes, is considered in the present study area to have been largely derived from erosion of continental soils developed on the adjacent areas of the Western High Atlas basin (Meseta and Anti-Atlas landmasses)

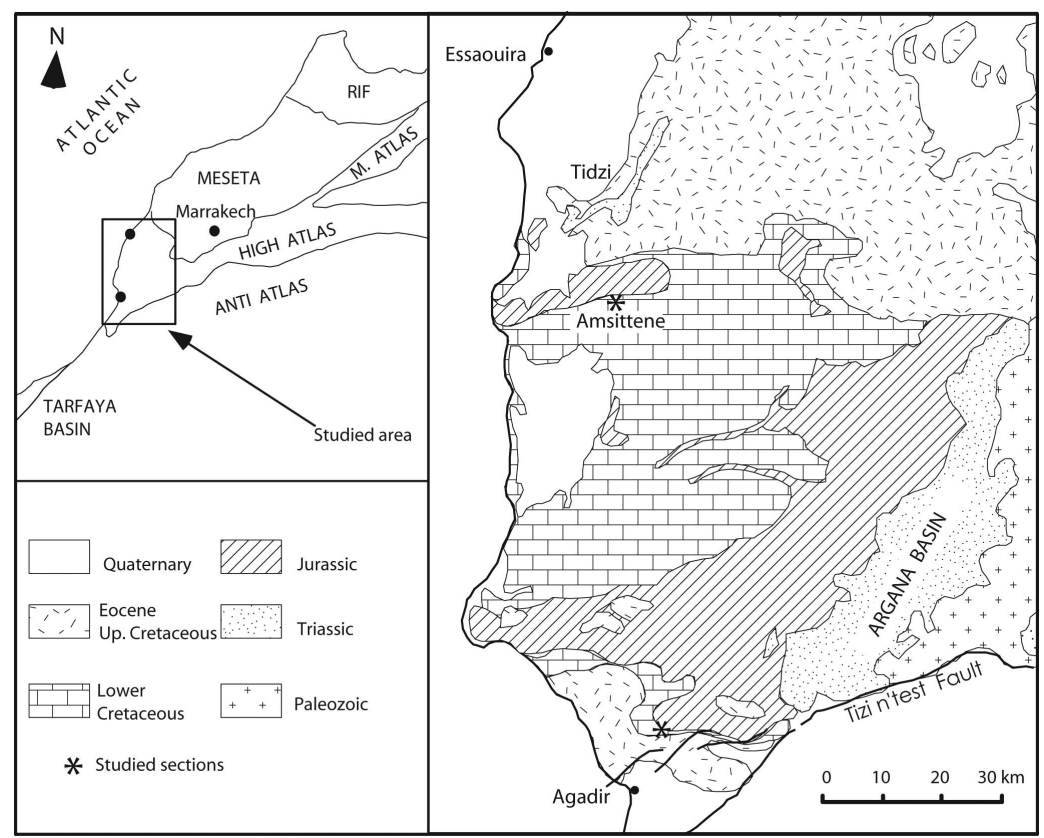

Figure 1. Geographic and geological map of the Agadir basin (Morocco). 
(Daoudi et al., 2008). The paleogeographic conditions prevailing during this period were important; the lowrelief morphology and tectonic quiescence, as well as the climate, were suitable for the formation of smectite in continental environments. This origin explains the abundance of the smectite deposits and their large geographical extent during this period.

\section{EXPERIMENTAL}

\section{Materials and methods}

Raw clay (TAG) samples were first crushed and sieved to $50 \mu \mathrm{m}$ and treated with $\mathrm{HCl}$ solution $(0.2 \mathrm{~N})$. The almost pure $\mathrm{Na}^{+}$-homoionic clay fraction (labeled as $\left.\mathrm{Na}^{+}-\mathrm{TAG}\right)$ was recovered by a procedure described elsewhere (Rhouta et al., 2008). To remove poorly crystalline Fe-rich impurities, which could be present as $\mathrm{Fe}$ oxides and/or gel Fe hydroxide (Goodman et al., 1976), the $\mathrm{Na}^{+}$-exchanged $<2 \mu \mathrm{m}$ fraction $\left(\mathrm{Na}^{+}-\mathrm{TAG}\right)$ was treated with a dithionite-citrate system buffered with sodium bicarbonate according to the procedure reported by Mehra and Jackson (1956). For this purpose, $1 \mathrm{~g}$ of $<2 \mu \mathrm{m}$ fraction powder was dispersed under stirring in a water bath at $80^{\circ} \mathrm{C}$ in solutions containing a mixture of $40 \mathrm{~mL}$ of sodium citrate $(0.3 \mathrm{~mol} / \mathrm{L})$ and $5 \mathrm{~mL}$ of sodium bicarbonate $(1 \mathrm{~mol} / \mathrm{L})$. Then, $500 \mathrm{mg}$ of sodium dithionite was added to this dispersion which was kept at $80^{\circ} \mathrm{C}$ under stirring for an additional $15 \mathrm{~min}$. Finally, the clay material was recovered by centrifugation at $604 \times \mathrm{g}$ using a Hermle Z300 device (Labortechnik, Wehingen, Germany) for $10 \mathrm{~min}$ and washed several times to remove excess reacting compounds. To perform the Greene-Kelly test (GreeneKelly, 1953a, 1953b, 1955), based on the Hofmann and Klemen (HK) effect (Hofmann and Klemen, 1950), to identify the particular smectite in question, the $\mathrm{Li}^{+}$-exchanged clay fraction (designated $\mathrm{Li}^{+}$-TAG) was prepared from $\mathrm{Na}^{+}-\mathrm{TAG}$ by exchanging $\mathrm{Li}^{+}$for $\mathrm{Na}^{+}$. Then, the $\mathrm{Li}^{+}$-saturated fraction $\left(\mathrm{Li}^{+}\right.$-TAG) was heat treated at $240^{\circ} \mathrm{C}$ for $24 \mathrm{~h}$ and solvated with ethylene glycol.

\section{Characterization techniques}

X-ray diffraction (XRD) patterns were recorded for the raw clay (TAG), the $<2 \mu \mathrm{m} \mathrm{Na}{ }^{+}$-saturated fraction $\left(\mathrm{Na}^{+}-\mathrm{TAG}\right)$, and the $<2 \mu \mathrm{m} \mathrm{Li}^{+}$-saturated fraction $\left(\mathrm{Li}^{+}\right.$TAG) on oriented flat plates over the range $2-60^{\circ} 2 \theta$ and on randomly oriented powders over the range $60-64^{\circ} 2 \theta$ using a Seifert XRD 3000TT diffractometer $(\mathrm{CuK} \alpha$ radiation), equipped with a diffracted-beam graphite monochromator in Bragg-Brentano configuration. Microstructural examinations and elemental compositions were performed on the $\mathrm{Na}^{+}$-exchanged $<2 \mu \mathrm{m}$ fraction $\left(\mathrm{Na}^{+}-\mathrm{TAG}\right)$ using a JEOL JSM 6400 scanning electron microscope (SEM) equipped with an energy dispersive X-ray TRACOR analyzer (EDS). For the SEM observations, powdered material was spread on a piece of double-sided carbon scotch tape and stuck on a sample holder. To ensure electron conduction, the powder was cathodic spray-coated with a thin silver film using an Edwards S150B metallizer. The thermogravimetric (TG) and differential thermal analysis (DTA) thermograms were collected using a Setaram Labsys apparatus on sample masses of $\sim 60 \mathrm{mg}$ and at a temperature ramp of $10 \mathrm{~K} / \mathrm{min}$ from ambient to $1273 \mathrm{~K}$. Solid-state ${ }^{27} \mathrm{Al}$ and ${ }^{29} \mathrm{Si}$ magic-angle spinning nuclear magnetic resonance (MAS-NMR) spectra were collected at room temperature using a Bruker Advance 500 spectrometer, equipped with a $4 \mathrm{~mm}$ cross-polarization magic-angle spinning probe fitted with a standard spinning assembly. The ${ }^{27} \mathrm{Al}$ MAS-NMR spectra were obtained at $130.32 \mathrm{MHz}$, while the ${ }^{29} \mathrm{Si}$ MAS-NMR spectra were recorded at $99.36 \mathrm{MHz}$. The ${ }^{27} \mathrm{Al}$ chemical shifts were recorded with respect to $\left[\mathrm{Al}\left(\mathrm{H}_{2} \mathrm{O}\right)_{6}\right]^{3+}$ as an external reference and the ${ }^{29} \mathrm{Si}$ chemical shifts were referred to tetramethylsilane (TMS). The cation exchange capacity (CEC) values of the raw clay (TAG) and its purified $\mathrm{Na}^{+}$-exchanged fraction $\left(\mathrm{Na}^{+}-\mathrm{TAG}\right)$ were determined according to two methods: one based on adsorption of hexamine cobalt complex (Mantin and Glaeser, 1960) and the other based on titration of clay particles with Methylene Blue (MB) solution. In the latter, the CEC was obtained at the point of zero charge (PZC) determined from the curve representing the variation of streaming induced potential (SIP) vs. the amount of MB added. The SIP measurements were carried out using a Müteck instrument, model PCD-02 (Müteck GmbH, Herrsching, Germany) (Jada et al., 2006; Bouna et al., 2010). The chemical compositions of the raw clay and its $<2 \mu \mathrm{m} \mathrm{Na}{ }^{+}$-saturated fraction were determined by Inductively Coupled Plasma (ICP) by means of a Thermo Electron Series X2 spectrometer (Thermo Fisher, Waltham, Massachusetts, USA) equipped with a Meinhard nebulizer and a SimulScan FTE type detector. Mid-infrared (MIR) spectroscopic studies were undertaken using a Nicolet 5700 spectrometer (CIRIMAT, Toulouse, France) under ambient conditions in the frequency range $400-4000 \mathrm{~cm}^{-1}$ using $\mathrm{KBr}$ pellets. The pellets contained a mixture of $2 \mathrm{mg}$ of clay material with $198 \mathrm{mg}$ of $\mathrm{KBr}(\sim 1 \mathrm{wt} . \%)$. The near-infrared (NIR) spectra were obtained using a Perkin Elmer Lambda 19 spectrophotometer equipped with an integrating sphere coated with $\mathrm{BaSO}_{4}$ which was used as a reference. The spectra were acquired on samples deposited on quartz flat plates from 4000 to $8000 \mathrm{~cm}^{-1}$ at a resolution of $5 \mathrm{~cm}^{-1}$. The specific surface area was measured from the adsorption-desorption isotherms of $\mathrm{N}_{2}$ at $77 \mathrm{~K}$ using an ASAP $2020 \mathrm{~V}$ $3.01 \mathrm{H}$ Adsorption Analyser from Micromeritics (Verneuil en Halatte, France). Prior to the $\mathrm{N}_{2}$ adsorption-desorption measurements, samples weighing $0.162 \mathrm{~g}$ were outgassed at $150^{\circ} \mathrm{C}$ for $24 \mathrm{~h}$. The specific surface area was determined by the Brunauner- EmmettTeller (BET) method (Brunauer et al., 1938). 


\section{RESULTS AND DISCUSSION}

Crystallographic analysis

The XRD patterns of the raw clay (TAG) and its $<2 \mu \mathrm{m}$ fraction $\left(\mathrm{Na}^{+}-\mathrm{TAG}\right)$ showed peaks characteristic of phyllosilicates at $6.04,12.30$, and $24.85^{\circ} 2 \theta$ corresponding to lattice spacings $\left(d_{h k l}\right)$ of $15.20,7.20$, and $3.58 \AA$, respectively (Figure $2 \mathrm{a}$ ). The reflection at $15.20 \AA$ was much more intense than those at 7.20 and $3.58 \AA$. The $15.20 \AA$ basal spacing is typical of smectitic clay saturated with a divalent cation such as $\mathrm{Ca}^{2+}$ the hydration shell of which consists of two equivalent layers of water in the usual laboratory conditions of water activity (Brown and Brindley, 1980; Holtpzapffel, 1985). The phyllosilicate peaks appeared notably broad with low intensities, indicating poor crystallinity and small average crystallite size. The peaks at $4.27 \AA$ $\left(20.76^{\circ} 2 \theta\right)$ and $3.35 \AA\left(26.58^{\circ} 2 \theta\right)$ suggested the presence of quartz (JCPDS file: $99-101-2545)$. The peaks at $3.85 \AA\left(23.07^{\circ} 2 \theta\right), 3.03 \AA\left(29.44^{\circ} 2 \theta\right), 2.49 \AA\left(35.99^{\circ} 2 \theta\right)$, $2.28 \AA\left(39.50^{\circ} 2 \theta\right), 2.09 \AA\left(43.19^{\circ} 2 \theta\right), 1.91 \AA\left(47.53^{\circ} 2 \theta\right)$, and $1.87 \AA\left(48.54^{\circ} 2 \theta\right)$ were ascribed to calcite $\mathrm{Mg}_{0.03} \mathrm{Ca}_{0.97} \mathrm{CO}_{3}$ (JCPDS file: 01-089-1304). Calcite was the most abundant associated mineral phase (the total amount of carbonate, quantified by the Bertrand calcimetry method was $\sim 20 \pm 5 \% \mathrm{v} / \mathrm{v})$. In the purified $\mathrm{Na}^{+}$-saturated fraction (Figure 2a), the calcite disappeared; some quartz reflections remained but with lower intensities. The phyllosilicate reflections were sharper and more intense. The most intense smectite reflection observed at $15.20 \AA$ in the raw clay was reduced to $12.48 \AA\left(6.40^{\circ} 2 \theta\right)$ in the $\mathrm{Na}^{+}$-exchanged $<2 \mu \mathrm{m}$ fraction, indicative of the saturation of interlayer spaces of smectite with $\mathrm{Na}^{+}$ions surrounded by the equivalent of a monolayer of water molecules (Brown and Brindley, 1980; Holtzapffel, 1985). The peak positions at 7.20 and $3.58 \AA$ remained unchanged indicating that they did not correspond to smectite.

The XRD patterns in the small-angle region, obtained from oriented flat plates of the separated clay fraction $\left(\mathrm{Na}^{+}-\mathrm{TAG}\right)$ after saturation with ethylene glycol, revealed that the reflection at $12.48 \AA$ expanded to $16.88 \AA$, indicating accessibility by polar molecules to the interlamellar space of the clay mineral (Figure $2 b$ ). Likewise, heat-treatment at $490^{\circ} \mathrm{C}$ in air led to the collapse of clay mineral interlamellar spacings from 12.48 to $9.92 \AA$ due to the dehydration of interlayer cations (Figure $2 \mathrm{~b}$ ). The amount of collapse $(\sim 2.56 \AA)$ was consistent with the presence of one equivalent of one water monolayer surrounding $\mathrm{Na}^{+}$interlayer cations (Velde, 1995; Holtzapffel, 1985; Brown and Brindley, 1980). These results confirmed the smectitic nature of the $<2 \mu \mathrm{m} \mathrm{Na}^{+}$-TAG fraction (Holtzapffel, 1985). Note that the peak at $7.20 \AA$ did not shift upon these two treatments, confirming the presence of a non-swellable phyllosilicate, namely kaolinite, further demonstrated by infrared (IR) spectroscopy. A very small peak (I) at $\sim 9.98 \AA\left(8.85^{\circ} 2 \theta\right)$ was observed in the glycolated $\mathrm{Na}^{+}$-TAG sample (Figure 2b) and, in accord with the geological setting and context described above, corresponded to illite. Semi-quantitative estimations, based on peak-height-ratios (Thorez, 1976; Holtzapffel, 1985;
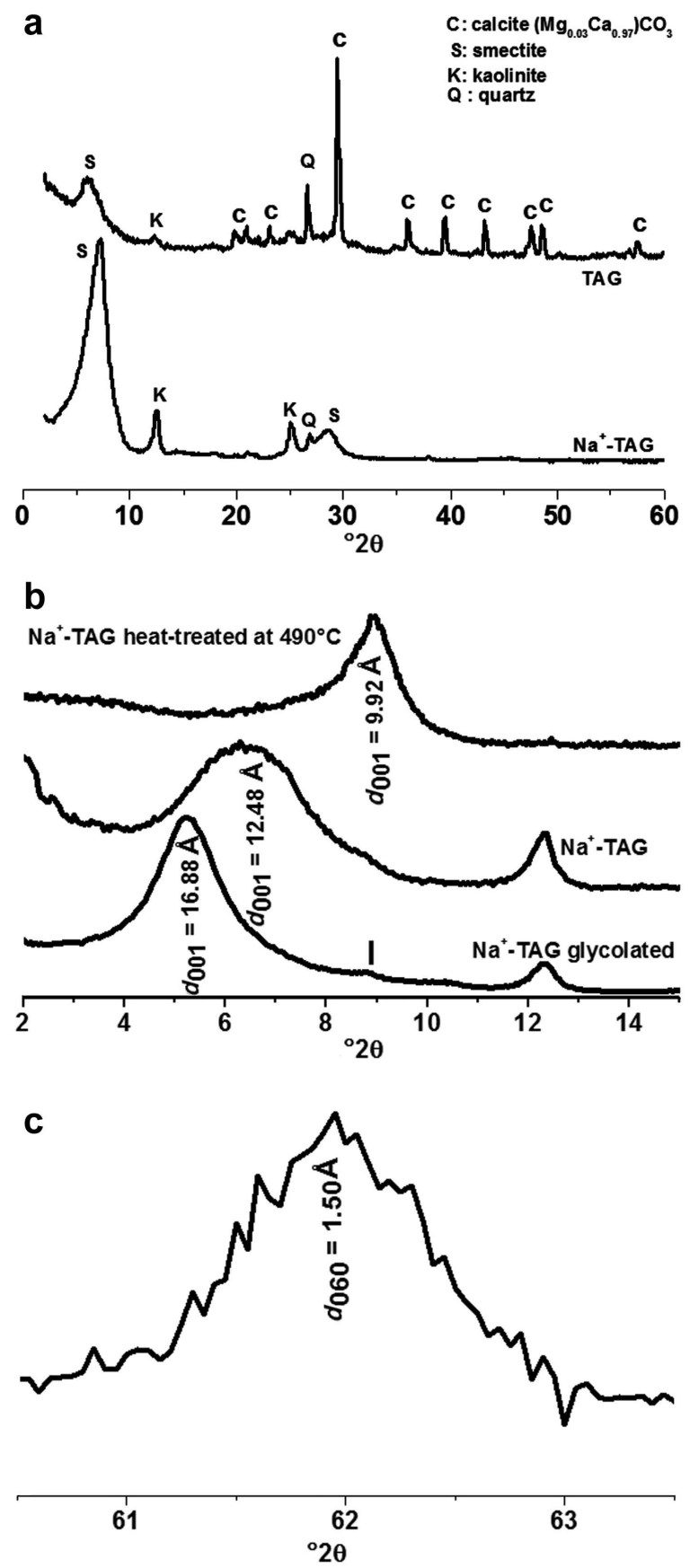

Figure 2. XRD patterns of the raw clay (TAG) and its isolated fine fraction $\left(\mathrm{Na}^{+}-\mathrm{TAG}\right)$ : (a) before (TAG) and after $\left(\mathrm{Na}^{+}-\mathrm{TAG}\right)$ purification; (b) XRD patterns in the small-angle region of the fine clay fraction $\left(\mathrm{Na}^{+}-\mathrm{TAG}\right)$ before and after successive different treatments; (c) detail of the $\mathrm{Na}^{+}$-TAG pattern in the region of the 060 reflection. 
Pevear and Mumpton, 1989; Galhano et al., 1999) of the principal reflections of the different mineral species, deduced from XRD patterns (Figure 2a,), indicated that the mineralogical composition of the $\mathrm{Na}^{+}$-TAG sample was roughly estimated at $\sim 98 \%$ phyllosicates and $\sim 2 \%$ quartz; for the phyllosilicates fraction, the composition was $\sim 93 \%$ beidellite, $\sim 7 \%$ kaolinite, and traces of illite.

The XRD pattern recorded over the range $58-66^{\circ} 2 \theta$ from randomly oriented air-dried powder of the fine clay fraction $\left(\mathrm{Na}^{+}-\mathrm{TAG}\right)$ (Figure 2c) showed a $d_{060}$ reflection at $1.50 \AA$, yielding a parameter $b$ of $\sim 8.98 \AA$. This value denoted that the $\mathrm{Na}^{+}$-exchanged $<2 \mu \mathrm{m}$ clay fraction $\left(\mathrm{Na}^{+}-\mathrm{TAG}\right)$ was a dioctahedral smectite (Brown and Brindley, 1980; Desprairies, 1983; Holtpzapfel, 1985; Parthasarathy et al., 2003).

In the dioctahedral sub-group, i.e. the montmorillonite-beidellite-nontronite series, the nontronite series is easy to distinguish as it is the Fe-rich end-member (Isphording, 1975; Caillère et al., 1982). The boundary between beidellite and montmorillonite is ambiguous and the term 'beidellite' only arose because of a controversy among mineralogists (Weir and GreeneKelly, 1962). Beidellite is now accepted to be the end member of dioctahedral Al-smectite with an average layer charge of $0.6-0.7$, created by the substitution of $\mathrm{Si}$ by Al in tetrahedral positions (Nadeau et al., 1985). Montmorillonite represents the Mg-for-Al octahedrally substituted end member of the dioctahedral smectite series (Brown and Brindley, 1980). Thus, the general formula proposed for ideal beidellite is $(0.5 \mathrm{Ca}, \mathrm{Na}$, $\mathrm{K})_{x} \mathrm{Al}_{4}\left(\mathrm{Si}_{8-x} \mathrm{Al}_{x}\right) \mathrm{O}_{20}(\mathrm{OH})_{4} \cdot n \mathrm{H}_{2} \mathrm{O}$ (Kloprogge, 2006). Beidellite can be distinguished from montmorillonite by the Greene-Kelly test (Greene-Kelly, 1953a, 1953b, 1955). This test, which utilizes the Hofmann-Klemen effect (Hofmann and Klemen, 1950), consists of $\mathrm{Li}^{+}$ saturation of clay minerals followed by heat treatment at $240^{\circ} \mathrm{C}$ for $24 \mathrm{~h}$. Upon solvation in ethylene glycol, montmorillonite, the negative charge of which is found almost entirely on the octahedral sheet, fails to reexpand. Beidellite and nontronite, however, in which all the negative charge is found on the tetrahedral sheet, do re-expand. The small-angle region of the XRD patterns showed that the pyrophillite-type structure of the $<2 \mu \mathrm{m}$ fraction of the TAG, characterized by a $9.90 \AA$ basal spacing, after $\mathrm{Li}^{+}$-saturation and heating at $240^{\circ} \mathrm{C}$ re-expanded to $16.70 \AA$ after ethylene-glycol solvation (Figure 3). This result suggested that charge-compensating $\mathrm{Li}^{+}$ions did not move into vacant octahedral sites upon heat-treatment but remained in the interlayer spaces of the clay mineral to neutralize the negative charge originating in the tetrahedral sheets due to cationic substitution. As suggested by Malla and Douglas (1987), the predominant charge of the $<2 \mu \mathrm{m}$ fraction of the TAG was in the tetrahedral sheets so it was likely to be either beidellite or nontronite. Note that the small peak (I) at $\sim 9.98 \AA$, corresponding to illite, appeared a little better resolved after the glycolation.

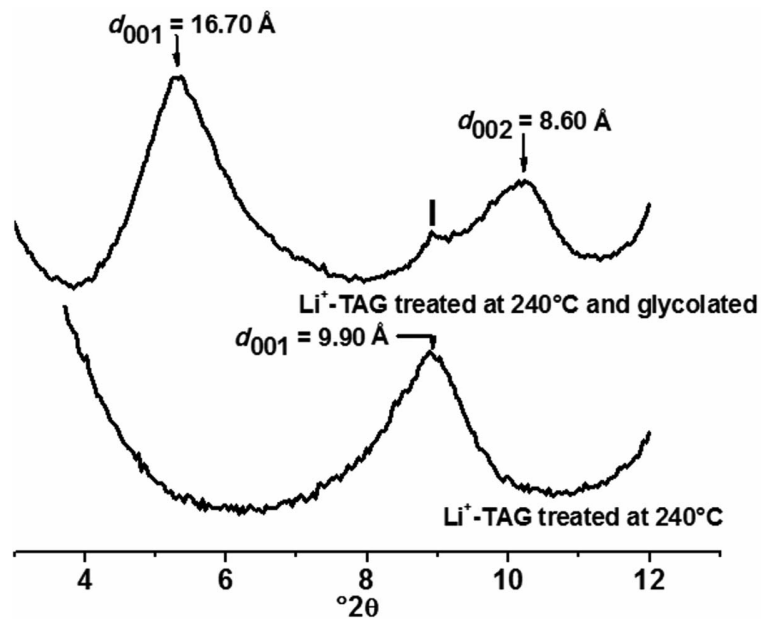

Figure 3. XRD patterns in the small-angle region of the fine clay fraction $\left(\mathrm{Na}^{+}-\mathrm{TAG}\right)$ after $\mathrm{Li}^{+}$saturation followed by heating at $240^{\circ} \mathrm{C}$ for $24 \mathrm{~h}\left(\mathrm{Li}^{+}-\mathrm{TAG} 240^{\circ} \mathrm{C}\right)$ and solvation in ethylene glycol ( $\mathrm{Li}^{+}-\mathrm{TAG} 240^{\circ} \mathrm{C}$ and glycolated).

\section{Structural and microstructural characterization}

The average diameter of the smectite plate-like particles is $1-2 \mu \mathrm{m}$, as noted by means of SEM (Figure 4); the image showed particles with a petaloid microstructure with irregular outlines, suggesting that they were derived from reworking. These crystals are very similar to smectite originating from soils in warm regions (Paquet, 1970; Trauth, 1977; Chamley, 1989). This confirms the detrital origin of the smectite clay in the Agadir basin, as was suggested by Daoudi et al. (2008).

\section{Thermal analysis}

The TG-DTA thermograms recorded from the raw clay and the fine clay fraction $\left(\mathrm{Na}^{+}-\mathrm{TAG}\right)$ revealed an endothermic effect for the two samples with a maximum at $115^{\circ} \mathrm{C}$, associated with a mass loss of $\sim 6.80 \%$

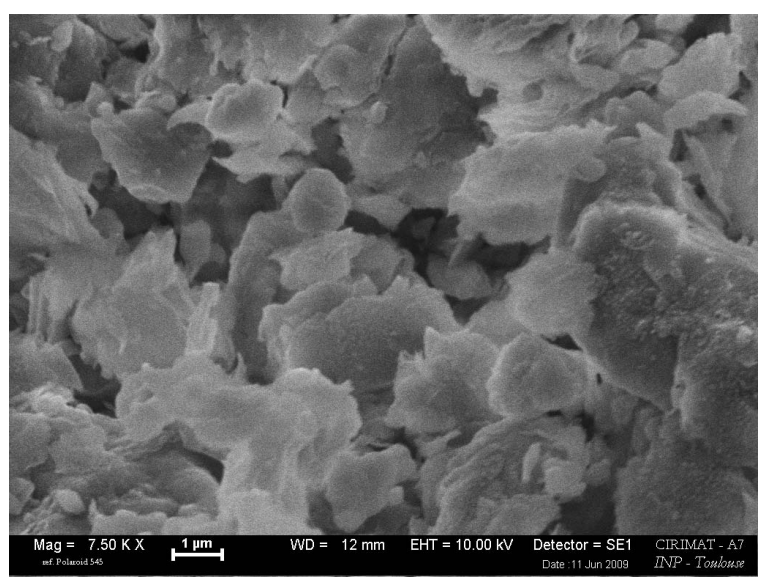

Figure 4. SEM image of raw TAG clay showing the petaloid morphology. 
(Figure 5). The peak was attributed to the removal of water physisorbed on the surfaces of particles and/or to dehydration of interlayer cations. Another endothermic peak was observed in the temperature range $300-600^{\circ} \mathrm{C}$, with a maximum at $\sim 510^{\circ} \mathrm{C}$, and with a corresponding weight loss of $\sim 4.26 \%$. The peak corresponded to the dehydroxylation of structural $\mathrm{OH}$. The dehydroxylation temperature was somewhat lower than those reported for other beidellite occurrences: $560^{\circ} \mathrm{C}$ (Post et al., 1997) and $595^{\circ} \mathrm{C}$ (Weir and Greene-Kelly, 1962), probably due to its poorly ordered crystal structure. This result supported the inference from the Greene-Kelly test above which suggested that the $<2 \mu \mathrm{m}$ fraction of the clay investigated here corresponded to beidellite rather than montmorillonite for which dehydroxylation occurs at $\sim 735^{\circ} \mathrm{C}$ (Post et al., 1997). Another endothermic peak was observed at $\sim 790^{\circ} \mathrm{C}$ for the $\mathrm{TAG}$ only with a corresponding mass loss of $\sim 11.41$ wt. $\%$ and was assigned to the removal of calcite. The absence of this peak in the $\mathrm{Na}^{+}$-exchanged $<2 \mu \mathrm{m}$ fraction confirmed the removal of carbonates by the purification treatment with $0.2 \mathrm{~N} \mathrm{HCl}$ solution.

The endothermic peaks observed at 870 and $890^{\circ} \mathrm{C}$ for the raw clay and the $<2 \mu \mathrm{m}$ fraction, respectively, associated with very small mass losses, probably corresponded to the completion of dehydroxylation of the clay minerals. Finally, the exothermic peak, observed for the two samples at $\sim 920^{\circ} \mathrm{C}$, close to that reported for beidellite from Black Jake Mine (Post et al., 1997, Weir and Greene-Kelly, 1962), was due to the crystallization of a new anhydrous mineral phase.

\section{${ }^{27} \mathrm{Al}$ and ${ }^{29} \mathrm{Si}$ solid state NMR analysis}

The ${ }^{27} \mathrm{Al}$ and ${ }^{29} \mathrm{Si}$ solid state NMR analysis revealed no significant differences between the raw clay and its $<2 \mu \mathrm{m}$ fraction. The ${ }^{27} \mathrm{Al}$ spectrum was similar to that reported for Black Jake beidellite (Woessner, 1989) and for synthetic beidellite (Kloprogge, 2006); it showed a series of spinning side-bands and two components at $4.2 \mathrm{ppm}$ and $68 \mathrm{ppm}$ corresponding to octahedral and tetrahedral environments of $\mathrm{Al}$, respectively (Figure 6a). The intensities of the corresponding signals yielded a ratio $\mathrm{Al}_{\text {tet }} /\left(\mathrm{Al}_{\text {oct }}+\mathrm{Al}_{\text {tet }}\right)$ of $\sim 0.21$, which indicated that Al mainly occupied octahedral sites. The peak at $68 \mathrm{ppm}$ again suggested that the $<2 \mu$ m clay fraction (Na+-TAG) corresponded to beidellite rather than to montmorillonite for which such a signal, when detected, was negligible (Woessner, 1989). The ${ }^{27} \mathrm{Al}$ NMR peaks were narrow, indicating a pure, well ordered beidellite (Woessner, 1989).

The ${ }^{29} \mathrm{Si}$ MAS-NMR spectrum was similar to those reported for the Unterrupsroth beidellite (Nadeau et al., 1985) and for synthetic beidellite (Kloprogge, 2006). Two intense, well resolved peaks at -108 and $-93 \mathrm{ppm}$ (Figure 6b) were seen. The peak at $-108 \mathrm{ppm}$ corresponded to the quartz impurity (Komarneni et al., 1986a) remaining in the purified $\mathrm{Na}^{+}$-exchanged fraction $\left(\mathrm{Na}^{+}-\mathrm{TAG}\right)$, in good agreement with XRD data (Figure 2a). The peak at $-93 \mathrm{ppm}$ was due to the tetrahedral coordination component $\left(\mathrm{Q}^{3}-0 \mathrm{Al}\right)$ of $\mathrm{Si}$, i.e. with four Si nearest neighbors (Nadeau et al., 1985; Kloprogge, 2006; Komarneni et al., 1986b). This resonance was broad and asymmetric due to a shoulder at $-86.7 \mathrm{ppm}$ associated with the component $\left(\mathrm{Q}^{3}-1 \mathrm{Al}\right)$, i.e. one Al nearest neighbor (Nadeau et al., 1985). This observation further supported the effective substitution of Si by $\mathrm{Al}$ in accordance with ${ }^{27} \mathrm{Al}$ MAS-NMR results, those reported for the beidellite from Unterrupsroth (Nadeau et al., 1985), and for synthetic beidellite (Kloprogge, 2006). Again, this observation proved that the $<2 \mu \mathrm{m}$ fraction investigated here could be identified as beidellite rather than montmorillonite for which the ${ }^{29} \mathrm{Si}$ MAS-NMR spectrum shows a single unresolved symmetric peak at a chemical shift of $\sim-95 \mathrm{ppm}$,

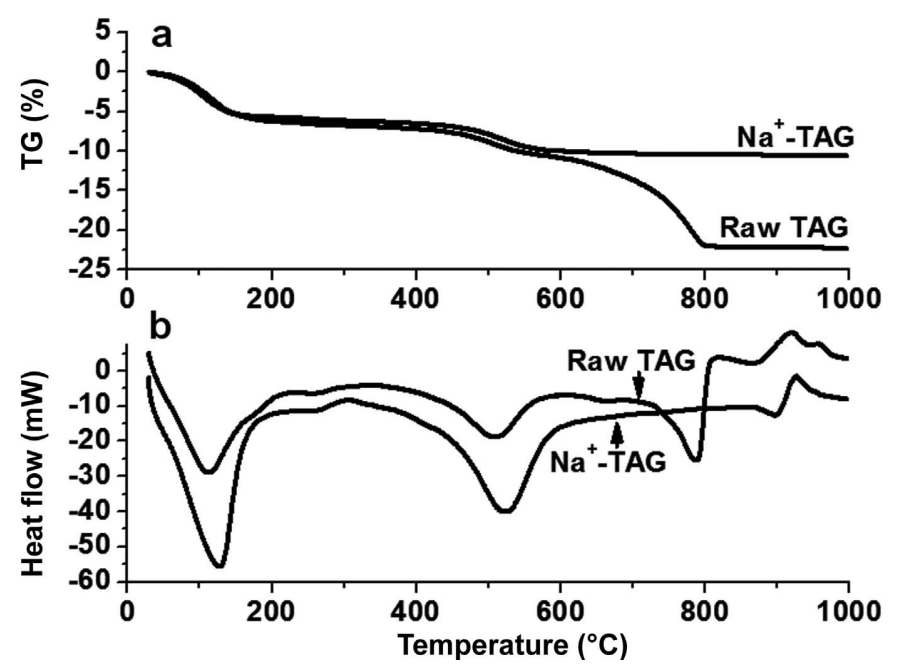

Figure 5. Thermal gravimetry (a) and DTA thermograms (b) of raw clay (TAG) and its fine fraction $\left(\mathrm{Na}^{+}-\mathrm{TAG}\right)$. 

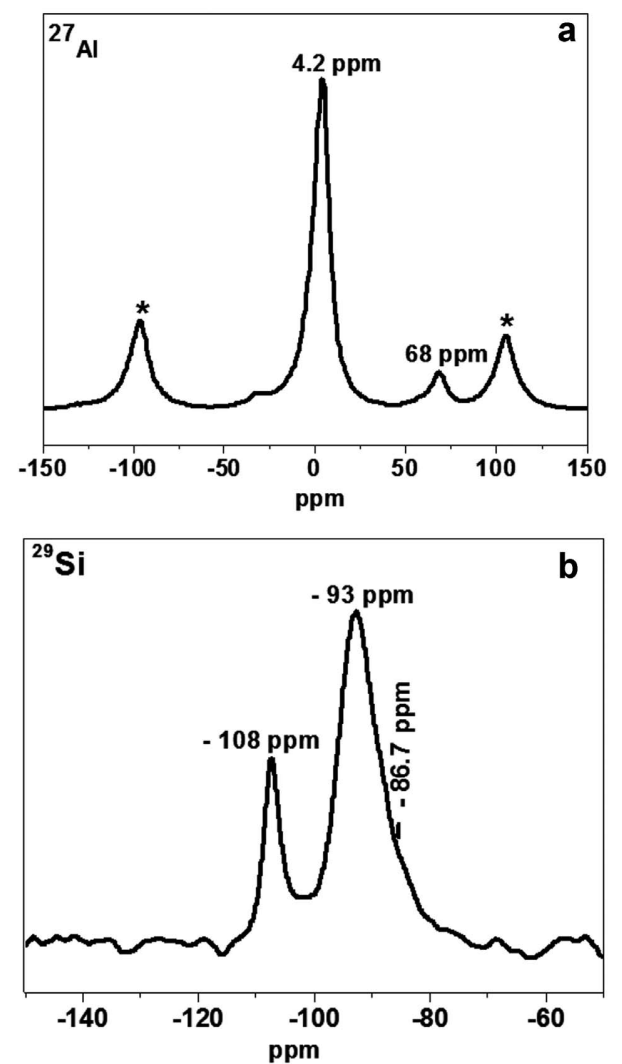

Figure $6 .{ }^{27} \mathrm{Al}$ (a) and ${ }^{29} \mathrm{Si}$ (b) MAS-NMR spectra of the $\mathrm{Na}^{+}-$ TAG $<2 \mu \mathrm{m}$ fraction.

corresponding to the component $\left(\mathrm{Q}^{3}-0 \mathrm{Al}\right)$ without Si-for-Al substitution (Komarneni, 1986a, 1986b).

\section{Cation exchange capacity (CEC) and chemical analysis}

The titration curves of the aqueous dispersions of raw clay and of its $<2 \mu \mathrm{m}$ fraction with methylene blue dye (MB) showed, in both cases, that the starting negative surface charge of the clay mineral were compensated progressively as the amount of $\mathrm{MB}\left(10^{-4} \mathrm{M}\right)$ added to aqueous dispersions $(20 \mathrm{mg} / 10 \mathrm{~mL})$ of raw clay, or of its $<2 \mu \mathrm{m}$ fraction, increased until it became neutral at $8 \times 10^{-3}$ and $11 \times 10^{-3} \mathrm{mmol} \mathrm{MB}$, respectively (Figure 7). This result indicates a high affinity of the solute for the adsorbents as revealed by the absence of color of any supernatants. Up to these amounts of MB added, the mechanism of cationic dye adsorption onto the clayey particle was mainly achieved by the process of cation exchange. Thus, the CEC values determined from the amount of MB added at the point of zero charge (PZC) were found to be $\sim 39 \mathrm{meq} / 100 \mathrm{~g}$ and $58.2 \mathrm{meq} / 100 \mathrm{~g}$ for the TAG raw clay and its purified $\mathrm{Na}^{+}$-TAG fine fraction, respectively. The CEC increased as the impurities associated with the clay were removed. The CEC value, determined from the adsorption of cobalt(III)hexamine onto $\mathrm{Na}^{+}$-exchanged $<2 \mu \mathrm{m}$ fraction $\left(\mathrm{Na}^{+}-\mathrm{TAG}\right)$, was the same order of magnitude

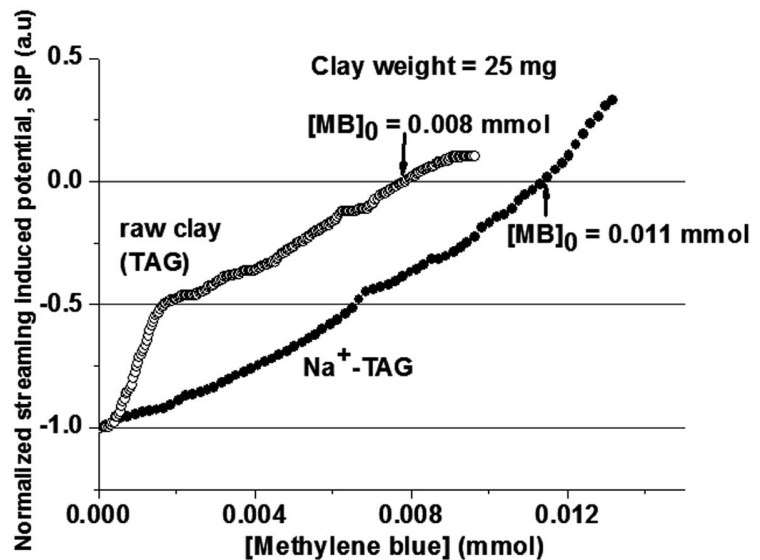

Figure 7. Variation of the streaming-induced potential with methylene blue (MB) concentration for raw clay (TAG) and for the $\mathrm{Na}^{+}$-homoionic $<2 \mu \mathrm{m}$ fraction $\left(\mathrm{Na}^{+}-\mathrm{TAG}\right)$ particles in aqueous dispersions.

$(59.7 \mathrm{meq} / 100 \mathrm{~g})$ as that assessed from the titration curve with MB. Beyond the PZC, the excess MB reversed the sign of clay charge from negative to positive (Figure 7), indicating specific adsorption of the cationic dye on the external clay surface, probably as aggregates (dimers, trimers, etc.) (Bergmann and O'Konski, 1963; Cenens and Schoonheydt, 1988) or over other active centers, such as $\mathrm{Si}-\mathrm{OH}$ groups, by hydrogen bonding (Casal et al., 1997). Knowing the surface area of one $\mathrm{MB}$ cation $\left(a_{\mathrm{MB}}=130 \AA^{2}\right)$ on one hand, and taking into account the values of the PZC determined above on the other hand, the specific surface areas of the raw clay and its purified $<2 \mu \mathrm{m}$ fraction were found to be $\sim 302$ and $446 \mathrm{~m}^{2} / \mathrm{g}$, respectively.

The chemical compositions of the dehydrated bulk TAG raw clay and its $<2 \mu \mathrm{m}$ fraction (Table 1 ) showed that the large amount of $\mathrm{CaO}$ in the raw clay, corresponding to carbonate (calcite), was eliminated upon purification with $\mathrm{HCl}$ solution $(0.2 \mathrm{~N})$, as suggested above by XRD analysis (Figure 2a), thermal analysis (Figure 5), and IR spectroscopy (Figure 8a). The smaller concentration of $\mathrm{Ca}$ accompanied by the increase in $\mathrm{Na}$ concentration in the $\mathrm{Na}^{+}$-TAG sample confirmed that the clay interlayer was saturated efficiently by $\mathrm{Na}^{+}$ions, in agreement with XRD analysis (Figure 2a). Comparison of the chemical composition of the $\mathrm{Na}^{+}$-saturated $<2 \mu \mathrm{m}$ clay fraction with different dioctahedral smectites showed that the $\mathrm{Na}^{+}$-TAG sample was richer in $\mathrm{Al}$ compared with montmorillonite and had a smaller $\mathrm{Fe}_{2} \mathrm{O}_{3}$ content than nontronite. These chemical compositions were in satisfactory agreement with those of beidellite from the Black Jake Mine and Unterrupsroth. Nevertheless, the $\mathrm{Na}^{+}$-exchanged $<2 \mu \mathrm{m}$ fraction investigated here contained significantly more $\mathrm{Fe}_{2} \mathrm{O}_{3}$ (7.52 wt.\%) than beidellite from the other occurrences $(0.5$ and $0.05 \%$ for Black Jake Mine and Unterrupsroth, respectively), while it was closer to that 
Table 1. Chemical composition of the raw clay (TAG) and its $<2 \mu \mathrm{m}$ fine fraction $\left(\mathrm{Na}^{+}-\mathrm{TAG}\right)$. The results are compared to literature data for other geographical regions: Black Jack Mine (Weir and Greene-Kelly, 1962) and Unterrupsroth (Nadeau et al., 1985).

\begin{tabular}{|c|c|c|c|c|c|c|}
\hline Samples & Wt.\% & $\mathrm{Na}^{+}-\mathrm{TAG}$ & $\begin{array}{c}\mathrm{Na}^{+}-\mathrm{TAG} \\
\text { Normalized } \\
\text { compositions } \\
\text { Wt. } \%\end{array}$ & (22 O atoms) & $\begin{array}{c}\text { Black Jack Mine } \\
\text { (Weir and Greene- } \\
\text { Kelly, 1962) } \\
\text { Wt. } \%\end{array}$ & $\begin{array}{c}\text { Unterrupsroth } \\
\text { (Nadeau et al., } \\
\text { 1985) } \\
\text { Wt.\% }\end{array}$ \\
\hline $\mathrm{SiO}_{2}$ & 50.76 & 58.91 & 62.82 & 7.51 & 59.30 & 48.98 \\
\hline $\mathrm{Al}_{2} \mathrm{O}_{3}$ & 16.93 & 22.92 & 24.71 & 3.48 & 36.11 & 24.76 \\
\hline $\mathrm{Fe}_{2} \mathrm{O}_{3}$ & 6.45 & 6.49 & 7.52 & 0.68 & 0.50 & 0.05 \\
\hline $\mathrm{Na}_{2} \mathrm{O}$ & 0.73 & 1.96 & 2.27 & 0.54 & 3.98 & - \\
\hline $\mathrm{CaO}$ & 19.92 & 0.17 & 0.2 & 0.03 & 0.02 & 3.62 \\
\hline $\mathrm{MgO}$ & 2.4 & 2.14 & 2.48 & 0.44 & 0.10 & 1.93 \\
\hline $\mathrm{K}_{2} \mathrm{O}$ & 1.28 & 1.54 & - & - & 0.11 & $<0.01$ \\
\hline $\mathrm{TiO}_{2}$ & 1.12 & 1.47 & - & - & - & 0.01 \\
\hline $\mathrm{MnO}$ & - & 0.01 & - & - & - & - \\
\hline $\mathrm{P}_{2} \mathrm{O}_{5}$ & - & 0.08 & - & - & - & - \\
\hline LOI & - & 4.31 & - & - & - & - \\
\hline Total & 99.59 & 100 & 100 & 12.68 & 100.12 & 79.36 \\
\hline
\end{tabular}

from Florida Mountain (12.6\%) (Post and Borer, 2002). Assuming that $\mathrm{Ti}$ and $\mathrm{K}$ were not contained in beidellite but rather in $\mathrm{Ti}$ dioxide and illite impurities, respectively, as mentioned, the compositions of the different elements properly belonging to pure beidellite were normalized with respect to $100 \%$. The chemical formula was deduced from the number of cations calculated on the basis of 22 oxygens (without taking into account $\mathrm{H}_{2} \mathrm{O}^{+}$and $\mathrm{H}_{2} \mathrm{O}^{-}$as the samples were dehydrated) (Rautureau et al., 2004) from the normalized compositions of beidellite. Taking into account the results of ${ }^{27} \mathrm{Al}$ and ${ }^{29} \mathrm{Si}$ solid MAS-NMR (Figure 6), the structural formula of the $<2 \mu \mathrm{m}$ fraction was determined as $\left(\mathrm{Si}_{7.51} \mathrm{Al}_{0.49}\right)\left(\mathrm{Al}_{2.99} \mathrm{Fe}_{0.68} \mathrm{Mg}_{0.33}\right)\left(\mathrm{Ca}_{0.03} \mathrm{Na}_{0.54} \mathrm{Mg}_{0.11}\right)$ $\mathrm{O}_{20}(\mathrm{OH})_{4}$. The formula showed that $\sim 60 \%$ of negative charge deficit (i.e. -0.49 e/unit cell) was located in the tetrahedral sheets with $\sim 40 \%$ (i.e. -0.33 e/unit cell) in the octahedral sheets, all being compensated by interlayer cations $(+0.82 \mathrm{e} / \mathrm{unit}$ cell $)$. These results were consistent with those of beidellites from other occurrences that exhibited a predominantly aluminiferous character. The interlayer CEC corresponding to the interlayer charge $\xi(+0.82$ e/unit cell $)$ exhibited by the structural formula above can be calculated from the following equation 1 (Besson et al., 1990; Mermut and Lagaly, 2001):

$$
\text { Interlayer } \mathrm{CEC}=10^{5} \times \xi / M
$$

where $M$ indicates the molar mass. The value calculated ( 108 meq/100 g) was consistent with those reported for dioctahedral smectite in general and for beidellite in particular (Bergaya et al., 1986). However, the value was larger than those measured above from cobalt(III)hexamine adsorption and from the titration curves with MB. The small value of the CEC measured was probably due to the coexistence with beidellite of kaolinite characterized by a very small CEC $(\sim 1-3 \mathrm{meq} / 100 \mathrm{~g})$ (Holtzapffel, 1985) and the remaining quartz.

In agreement with Malla and Douglas (1987), the magnitude of the tetrahedral charge given above was $>50 \%$, which permitted identification of the $<2 \mu \mathrm{m}$ purified fraction as beidellite. In the Greene-Kelly test, some $\mathrm{Li}^{+}$ions were clearly migrating to the octahedral sheets upon heating of the $\mathrm{Li}^{+}$-TAG sample to effectively neutralize the $\sim 40 \%$ octahedral charge, while the majority remained in the interlayer spaces to compensate the $60 \%$ tetrahedral charge and caused swelling of the clay mineral as shown by XRD (Figure 3 ). According to Desprairies (1983), the crystallographic $b$ parameter of smectites could be assessed from the sum, $S$, of cations $\mathrm{Fe}$ and $\mathrm{Mg}$ per half unit cell located in tetrahedral and octahedral positions in the structural formula:

$$
b(\AA)=8.953+0.087 S \pm 0.015 \AA
$$

The value found $(9.00 \pm 0.015 \AA)$ by this method was the same as that determined from the XRD data $(8.98 \AA)$ (Figure 2c).

\section{Infrared spectroscopy}

In agreement with XRD analysis (Figure 2a) and thermal analysis (Figure 5), the MIR spectra of the raw clay (TAG) and its $<2 \mu \mathrm{m}$ fraction $\left(\mathrm{Na}^{+}-\mathrm{TAG}\right)$ confirmed that the calcite impurities present in the raw clay were removed completely by the purification treatment as shown by the disappearance of the carbonate bands at 1434 and $872 \mathrm{~cm}^{-1}$ (Figure 8a). The quartz bands at 797 and $779 \mathrm{~cm}^{-1}$ were still observed in the $<2 \mu \mathrm{m}$ fraction but with lower intensities than in the raw clay, in good agreement with the XRD analysis (Figure 2a). The bands at 3622 and $912 \mathrm{~cm}^{-1}$ are characteristic of dioctahedral smectites (Caillère et al., 1982) and originate from stretching $(v)$ and deformation $(\delta)$ vibrations, respec- 

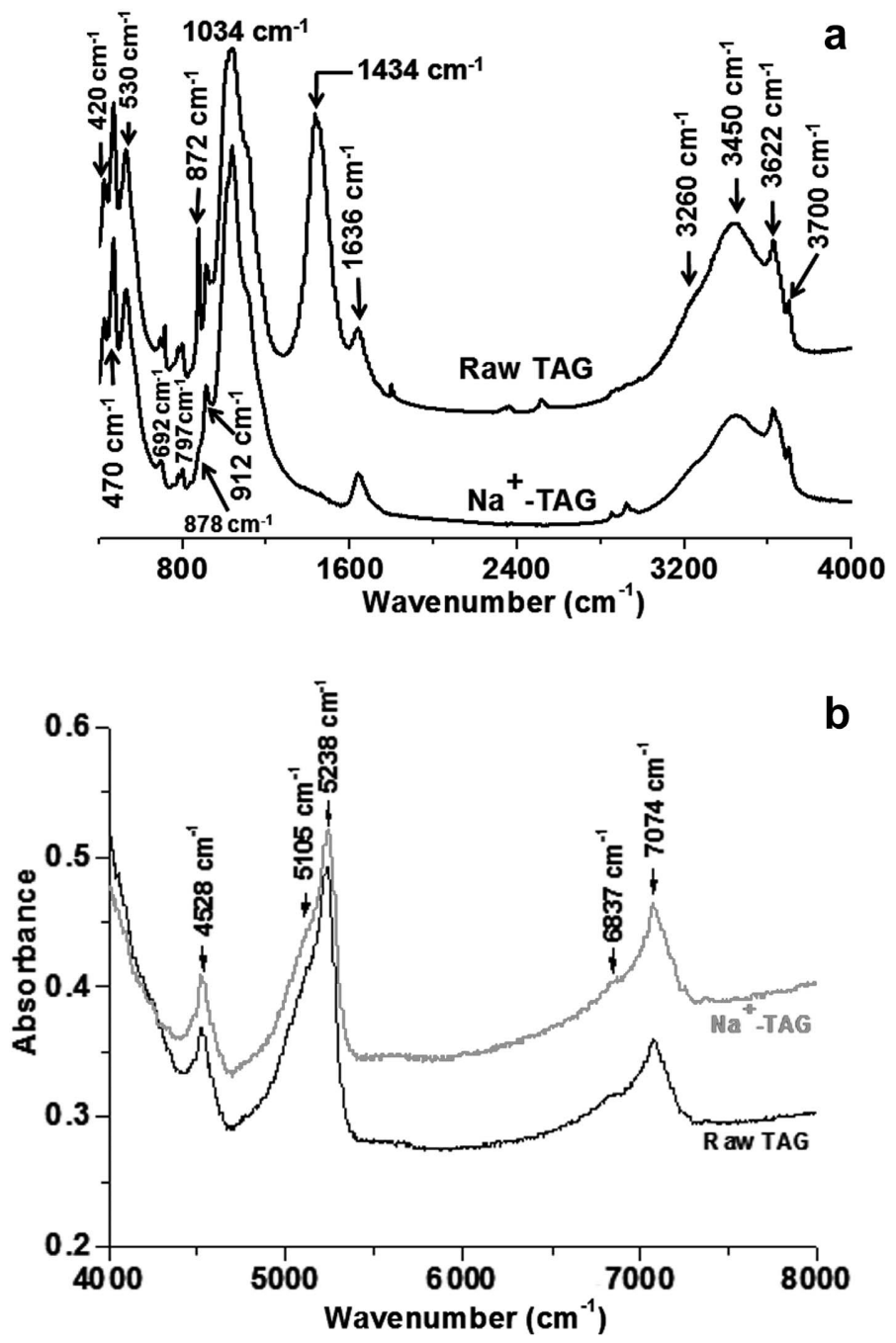

Figure 8. Mid-infrared (a) and near-infrared spectra (b) of clay samples before (TAG) and after the purification treatment (Na ${ }^{+}$-TAG).

tively, of hydroxyls in the $[\mathrm{AlAl}-\mathrm{OH}]$ configuration (Farmer, 1974). The peak at $912 \mathrm{~cm}^{-1}$ presented a shoulder at $\sim 878 \mathrm{~cm}^{-1}$, which could be ascribed to deformation modes of AlFe(III)OH groups (Russel et al., 1970; Farmer, 1974). The corresponding stretching vibration, generally observed at $\sim 3596 \mathrm{~cm}^{-1}$ (Frost et al., 2002), probably overlapped with the large band centered around $3622 \mathrm{~cm}^{-1}$. Even treatments of the sample for $4 \mathrm{~h}$ at 200 and $400^{\circ} \mathrm{C}$ failed to resolve this absorption band. The presence of structural $\mathrm{Fe}(\mathrm{III})$ in an octahedral environment rather than in a tetrahedral environment of the isolated smectite investigated here was further supported by the observation of the stretching vibration band of $\mathrm{Si}-\mathrm{O}$ at $1034 \mathrm{~cm}^{-1}$, in agreement with Goodman et al. (1976). The present authors reported that the position of the $\mathrm{Si}-\mathrm{O}$ stretching band shifted to lower frequency $\left(\sim 1001 \mathrm{~cm}^{-1}\right)$ as the amount of tetrahedral $\mathrm{Fe}$ (III) increased. The absence of a band at $\sim 825 \mathrm{~cm}^{-1}$, characteristic of deformation vibrations of $(\mathrm{Fe}(\mathrm{III}))_{2} \mathrm{OH}$ units, suggested that the $<2 \mu \mathrm{m}$ fraction of the TAG clay could not be identified as nontronite (Fialips et al., 2002; Madejová et al., 2009). The band centered at $1636 \mathrm{~cm}^{-1}$ was due to the deformation mode of physically adsorbed water molecules. This band was broad so it probably overlapped bands at 1680 and $1650 \mathrm{~cm}^{-1}$, deformation modes of water coordinated to interlayer cations and water in the hydration sphere of cations, respectively (Frost et al., 2002). The corresponding stretching vibration bands were clearly observed at 3260 and $3450 \mathrm{~cm}^{-1}$, respectively. The intense and sharp bands at 420,470 , and $530 \mathrm{~cm}^{-1}$ were ascribed to $\mathrm{SiO}$ deformation. The shoulders observed at 692 and $3700 \mathrm{~cm}^{-1}$ corresponded to kaolinite, in good agreement with XRD analysis (Figure 2a, 2b).

The results above were further supported by NIR analysis. Indeed, NIR spectra of the raw clay (TAG) and 
its $<2 \mu \mathrm{m}$ fraction showed three characteristic ranges corresponding to the first overtones of the $\mathrm{O}-\mathrm{H}$ stretching modes $\left(2 v_{\mathrm{OH}}\right)\left(6500-7500 \mathrm{~cm}^{-1}\right)$, the combination bands of $\mathrm{H}_{2} \mathrm{O}(v+\delta)_{\mathrm{H}_{2} \mathrm{O}}\left(5000-5500 \mathrm{~cm}^{-1}\right)$, and the stretching-deformation combination of $\mathrm{OH}(v+\delta)_{\mathrm{OH}}$ $\left(4350-4700 \mathrm{~cm}^{-1}\right)$ (Frost et al., 2002) (Figure 8b). The appearance of the overtone bands at lower wavenumbers than twice the wavenumber of the fundamental mode $\left(v_{\mathrm{OH}}\right)$ was due to the anharmonic character of vibrations (Madejová et al., 2009). In the high-frequency range, the main absorption centered at $7074 \mathrm{~cm}^{-1}$ might correspond to $2 v_{\mathrm{Al}_{2} \mathrm{OH}}\left(\mathrm{v}_{\mathrm{Al}_{2} \mathrm{OH}}=3622 \mathrm{~cm}^{-1}\right)$ (Bishop, 2005; Madejová, 2003; Carriati et al., 1981). The band was broad so it probably overlapped contributions of different $\mathrm{OH}$ overtones (Madejová et al., 2009) and could also contain contributions of overtones of $\mathrm{AlFe}(\mathrm{III}) \mathrm{OH}$ the absorption of which was reported by Frost et al. (2002) to occur at $7070 \mathrm{~cm}^{-1}(v=$ $3596 \mathrm{~cm}^{-1}$ ) for ferruginous smectite. Nevertheless, in agreement with MIR spectroscopy, no contribution of overtones of $\mathrm{OH}$-stretching modes from $\mathrm{Fe}_{2} \mathrm{OH}$ entities were observed at lower wavenumbers, i.e. $\sim 6965 \mathrm{~cm}^{-1}$ in nontronites (Frost et al., 2002). Thus, the $<2 \mu \mathrm{m}$ fraction of the TAG clay could not be ascribed to nontronite. The shoulder observed at $6837 \mathrm{~cm}^{-1}$ could be due instead to $2 v_{\mathrm{OH}}$ of water $\left(v_{\mathrm{OH}}=3450 \mathrm{~cm}^{-1}\right)$ coordinated to the clay mineral (Frost et al., 2002; Madejová et al., 2009). The sharp and intense hydroxyl combination band $(v+\delta)_{\mathrm{OH}}$ at $4528 \mathrm{~cm}^{-1}$ could be assigned to $\mathrm{Al}_{2} \mathrm{OH}\left(\mathrm{v}=3622 \mathrm{~cm}^{-1}\right.$ and $\left.\delta=912 \mathrm{~cm}^{-1}\right)$. The position of this hydroxyl combination absorption was greater than that corresponding to (AlFe(III)OH) for ferruginous smectite or that due to $\mathrm{Fe}_{2} \mathrm{OH}$ for nontronite (Frost et al., 2002), but close to that corresponding to beidellite (Gates, 2005). Moreover, Post and Noble (1993) suggested a direct linear correlation (Equation 3) between the position of this hydroxyl combination band and Al content for the dioctahedral smectite series, including the montmorillonite and beidellite minerals, which was as follows:

$$
\begin{aligned}
& \lambda^{-1}\left(\mathrm{~cm}^{-1}\right)= \\
& \quad(5.38 \pm 0.04)\left(\% \mathrm{Al}_{2} \mathrm{O}_{3}\right)+(4412.8 \pm 0.90)
\end{aligned}
$$

As the wt. $\%$ of $\mathrm{Al}_{2} \mathrm{O}_{3}$ determined above by chemical analysis in the $<2 \mu \mathrm{m} \mathrm{Na} \mathrm{Na}^{+}$homoionic fraction $\left(\mathrm{Na}^{+}-\mathrm{TAG}\right)$ was $\sim 22.92 \%$, the corresponding calculated absorption $\left(4536.10 \pm 1.80 \mathrm{~cm}^{-1}\right)$ was of the same order of magnitude as that $\left(4528 \mathrm{~cm}^{-1}\right)$ found by NIR analysis. These results suggested that the octahedral positions of the $<2 \mu \mathrm{m}$ fraction of the TAG clay was dominated by Al ions which were partly replaced by $\mathrm{Fe}(\mathrm{III})$ ions. In the mid-IR frequency range, the absorption at $5238 \mathrm{~cm}^{-1}$ was attributed to water combination bands $(v+\delta)_{\mathrm{H}_{2} \mathrm{O}}$ arising from the coordinated water with the deformation frequency of $1680 \mathrm{~cm}^{-1}$ while the band at $5105 \mathrm{~cm}^{-1}$ arose from the interlayer water with a bending frequency of $1636 \mathrm{~cm}^{-1}$ (Frost et al., 2002; Cariati et al., 1981).

\section{Textural properties}

The adsorption-desorption isotherms of nitrogen on TAG raw clay and its purified fine fraction $\left(\mathrm{Na}^{+}-\mathrm{TAG}\right)$ revealed that they were of type IV, with a hysteresis loop of type $\mathrm{H} 4$, according to the classification of the International Union of Pure and Applied Chemistry (IUPAC) (Sing et al., 1985) (Figure 9a). The same isotherm shape was recently reported for natural beidellite from a rock matrix (Australia) (Blain et al., 2011). The type IV isotherm is characteristic of porous adsorbents, with pore sizes in the range 1.5-100 nm, while a hysteresis loop of type H4 occurs for samples having narrow pore-size distributions. The BET specific surface area $\left(S_{0}\right)$, the micropore surface area $\left(S_{\text {mic }}\right)$, and the external surface area $\left(S_{\mathrm{ex}}\right)$ were determined from these isotherms, using the BET equation applied for the relative pressure range $0.02<P / P_{0}<0.33$. Likewise, the total volume of pores $\left(V_{\mathrm{p}}\right)$ as well as the micropore volume $\left(V_{\text {mic }}\right)$ were assessed from the BET $\left(\mathrm{N}_{2}\right)$ adsorption-desorption isotherms according to the BJH (Barett et al., 1951) and the Delon and Dellyes (1967) methods. The overall results gathered in Table 2 showed
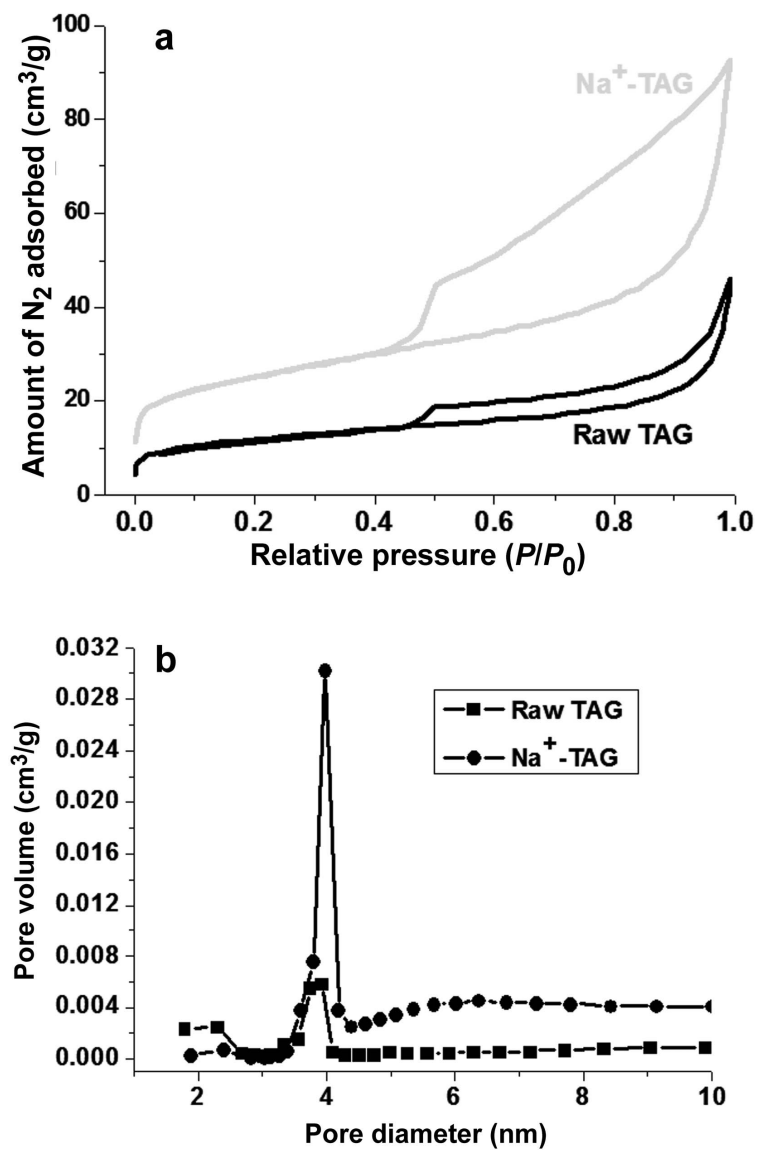

Figure 9. Adsorption-desorption $\left(\mathrm{N}_{2}\right)$ isotherms (a) and porosity distribution (b) of the raw clay (TAG) and the separated fine fraction $\left(\mathrm{Na}^{+}-\mathrm{TAG}\right)$. 
Table 2. BET specific surface area $\left(S_{0}\right)$, average radius of pores $\left(r_{\mathrm{p}}\right)$, total pore volume $\left(V_{\mathrm{p}}\right)$, microporous volume $\left(V_{\text {mic }}\right)$, surface area of the micropores $\left(S_{\text {mic }}\right)$, and external surface area of raw clay (TAG) and its purified $<2 \mu \mathrm{m}$ fraction $\left(\mathrm{Na}^{+}-\mathrm{TAG}\right)$ $\left(S_{\text {ext }}\right)$.

\begin{tabular}{lcccccc}
\hline Sample & $\begin{array}{c}S_{0} \\
\left(\mathrm{~m}^{2} / \mathrm{g}\right)\end{array}$ & $\begin{array}{c}r_{\mathrm{p}} \\
(\mathrm{A})\end{array}$ & $\begin{array}{c}V_{\mathrm{p}} \\
\left(\mathrm{cm}^{3} / \mathrm{g}\right)\end{array}$ & $\begin{array}{c}V_{\text {mic }} \\
\left(\mathrm{cm}^{3} / \mathrm{g}\right)\end{array}$ & $\begin{array}{c}S_{\text {micr }} \\
\left(\mathrm{m}^{2} / \mathrm{g}\right)\end{array}$ & $\begin{array}{c}S_{\text {ext }} \\
\left(\mathrm{m}^{2} / \mathrm{g}\right)\end{array}$ \\
\hline Raw TAG & 43.86 & 65 & 0.071 & 0.007 & 13.45 & 30.41 \\
$\mathrm{Na}^{+}$-TAG & 82.20 & 66 & 0.1357 & 0.012 & 24.52 & 57.68
\end{tabular}

that, by comparing the raw TAG clay and its purified fraction, the specific surface area and the total pore volume increased dramatically as the impurities were eliminated. The porosity distribution determined from the BET $\left(\mathrm{N}_{2}\right)$ adsorption-desorption isotherms according to BJH or the t-plot (deBoer et al., 1966) methods revealed no significant differences. For the two samples, a single and narrow peak centered at $4 \mathrm{~nm}$ indicative of the predominant presence of mesopores (Figure 9b) was shown instead. As expected, these specific BET surface areas were considerably smaller than the corresponding specific surface areas, as described above for the PZC from the titration curves with MB (Figure 7), due to the intercalation of the $\mathrm{MB}$ cations into the smectite interlayer spaces.

\section{CONCLUSIONS}

The present study was devoted to the mineralogical and physico-chemical characterization of clay from the Agadir basin, Morocco, and of its $<2 \mu \mathrm{m}$ fraction. The clay consisted of phyllosilicates along with carbonates (calcite) and quartz impurities. Observations by SEM showed a petaloid microstructure of flat phyllosilicate particles, typical of smectite. This observation was further supported by XRD analysis showing the shifts of the basal reflection $d_{001}$ upon specific glycolation and heat treatments. The $b$ parameter of the unit cell (8.98 $\AA$ ), determined by XRD, and the presence of IR bands characteristic of $\mathrm{Al}_{2} \mathrm{OH}$ and $\mathrm{AlFe}(\mathrm{III}) \mathrm{OH}$ proved the dioctahedral character of the isolated smectite. The dehydroxylation temperature observed at $\sim 510^{\circ} \mathrm{C}$ and the re-expansion in ethylene glycol after $\mathrm{Li}^{+}$-saturation and heating at $240^{\circ} \mathrm{C}$ for $24 \mathrm{~h}$ proved the beidellite structure of the $<2 \mu \mathrm{m}$ fraction of the clay investigated. In addition, the small $\mathrm{Fe}_{2} \mathrm{O}_{3}$ and large $\mathrm{Al}_{2} \mathrm{O}_{3}$ contents on one hand, and the absence of fundamental $\mathrm{OH}$-stretching modes in MIR spectra and in their corresponding first overtones in NIR spectra arising from $\mathrm{Fe}_{2} \mathrm{OH}$ units on the other, suggested strongly that the separated $<2 \mu \mathrm{m}$ fraction could not be identified as nontronite. The beidellite exhibited a chemical composition which was slightly different from that of beidellites from other occurrences in that it contained $\mathrm{Al}$ and Fe. The MASNMR showed predominant Al-for-Si substitution and the structural formula was determined as $\left(\mathrm{Si}_{7.51} \mathrm{Al}_{0.49}\right)$ $\left(\mathrm{Al}_{2.99} \mathrm{Fe}_{0.68} \mathrm{Mg}_{0.33}\right)\left(\mathrm{Ca}_{0.03} \mathrm{Na}_{0.54} \mathrm{Mg}_{0.11}\right) \mathrm{O}_{20}(\mathrm{OH})_{4}$. The
CEC was $\sim 108 \mathrm{meq} / 100 \mathrm{~g}$ whereas it developed a BET surface area of $\sim 82.2 \mathrm{~m}^{2} / \mathrm{g}$ and exhibited mesopores which were mainly $4 \mathrm{~nm}$ in diameter.

The study reported the occurrence of an aluminiferous beidellite-rich clay from Agadir basin the detrital origin of which testified to its great abundance. This in contrast to other beidellites which typically occur in small amounts, generally associated with other clay minerals, in veins of hydrothermally altered igneous rocks. As the beidellitic clay is well known for its catalytic property due to its strong acidity, as well as for its ability to be chemically modified, the study has demonstrated that the Agadir Basin has significant potential for exploitation of its beidellite deposits.

\section{ACKNOWLEDGMENTS}

Financial support by the 'Convention de cooperation CNRST-Maroc/CNRS-France' (chemistry project $\mathrm{N}^{\circ}$ 04/08), the 'Programme de Coopération Scientifique Interuniversitaire de l'Agence Universitaire de la Francophonie' ( $\mathrm{N}^{\mathrm{o}} 63$ 13PS826) and the 'Programme d'Action Intégrée Volubilis' ( $\left.\mathrm{N}^{\mathrm{o}} \mathrm{MA}-08-185\right)$ is acknowledged gratefully. The authors thank Mr J. Pérez-Carvajal and Dr Pilar Aranda from the ICMM-CSIC specific surface area and porosity analysis laboratory and Dr Rachid Hakkou from the FSTG analysis service for repeating sample measurements of surface area and of chemical analysis by ICP. The authors are also grateful to Prof. Mohamed Said Mehahad and Prof. Hakim Boumert for their help in revising the language.

\section{REFERENCES}

Alexandre, M. and Dubois, P. (2000) Polymer-layered silicate nanocomposites: preparation, properties and uses of a new class of materials. Materials Science and Engineering, 28, $1-63$.

Barett, E.P., Joyner, L.G., and Halenda, P.F. (1951) The determination of pore volume and area distribution in porous substances. Computation of nitrogen isotherms. Journal of the American Chemical Society, 73, 373-380.

Bergaya, F., Strolazzo, J.P., Trauth, N., and Van Damme, H. (1986) Caractérisation de la fraction fine de trois argiles de gisements exploités comme substance utile en France, Tunisie et Arabie. Clay Minerals, 21, 965-970.

Bergmann, K. and O'Konski, C.T. (1963) A spectroscopic study of methylene blue monomer, dimer and complexes with montmorillonite. Journal of Physics and Chemistry, 67, 2169-2177.

Besson, G., Decarreau, A., Manceau, A., Sanz, J., and Suquet, H. (1990) Organisation interne du feuillet. Pp. 5-25 in: Matériaux argileux: structures, propriétés et applications (A. Decarreau, editor). Société Française de Minéralogie et 
de Cristallographie et Groupe Français des Argiles, 586 pp Bishop, J.L. (2005) Water on Mars and life. Advances in Astrobiology and Biophysics, 4, 65-96.

Blain, P., Wayde, N.M., and Ray, L.F. (2011) Organosilane grafted acid-activated beidellite clay for the removal of nonionic alachlor and anionic imazaquin. Applied Surface Science, 257, 5552-5558.

Bouna, L., Rhouta, B., Amjoud, M., Jada, A., Maury, F., Daoudi, L., and Senocq, F. (2010) Correlation between electrokinetic mobility and ionic dyes adsorption of Moroccan stevensite. Applied Clay Science, 48, 527-530.

Brown, G. and Brindley, G.W. (1980) X-ray procedures for clay minerals identification. Pp. 305-360 in: Crystal Structures of Clay Minerals and their X-ray Identification (G.W. Brindley \& G. Brown, editors). Monograph 5, Mineralogical Society, London.

Brunauer, S., Emmet, P.H., and Teller, E. (1938) Adsorption of gases in multimolecular layers. Journal of the American Chemical Society, 60, 309-319.

Butt, A. (1982) Micropaleontological bathymetry of the Cretaceous of Western Morocco. Palaeogeography, Palaeoclimatology, Palaeoecology, 37, 235-275.

Caillère, S., Henin, S., and Rautureau, M. (1982) Minéralogie des Argiles: 1. Structures et Propriétés Physico-chimiques. 2. Classification et Nomenclatures. Masson, Paris, $184 \mathrm{pp}$.

Carriati, F., Erre, L., Micera, G., Piu, P., and Gessa, C. (1981) Water molecules and hydroxyl groups in montmorillonite as studied by near infrared spectroscopy. Clays and Clay Minerals, 29, 157-159.

Casal, B., Merino, J., Ruiz-Hitzky, E., Gutierrez, E., and Alvarez, A. (1997) Characterization, pillaring and catalytic properties of a saponite from Vicálvaro, Madrid, Spain. Clay Minerals, 32, $41-54$.

Cenens, J. and Schoonheydt, R.A. (1988) Visible spectroscopy of methylene blue on hectorite, Laponite B and barasym in aqueous suspension. Clays and Clay Minerals, 36, 214-224.

Chamley, H. (1989) Clay Sedimentology. Springer, Berlin, $623 \mathrm{pp}$.

Daoudi, L. and Deconninck, J.F. (1994) Contrôles paléogéographique et diagénétique des successions sédimentaires argileuses du bassin atlasique au Crétacé (Haut Atlas occidental, Maroc). Journal of African Earth Sciences, 18 , $123-134$.

Daoudi, L., Rocha, F., Ouajhain, B., Dinis, J.L., Chafiki, D., and Callapez, P. (2008) Palaeoenvironmental significance of clay minerals in Upper Cenomanian-Turonian sediments of the western High Atlas Basin (Morocco). Clay Minerals, 432, 615-630.

Daoudi, L., Ouajhain, B., Rocha, F., Rhouta, B., and Chafiki, D. (2010) Comparative influence of burial depth on the clay mineral assemblage of the Agadir-Essaouira basin (Western High Atlas, Morocco). Clay Minerals, 45, 413-427.

Darder, M., Collila, M., and Ruiz-Hitzky, E. (2005) Chitosanclay nanocomposites: application as electrochemical sensors. Applied Clay Science, 28, 199-208.

deBoer, J.M., Lippens, B.C., Linsen, B.G., Broekhoff, J.C.P., Van der Heuvel, A., and Osinga, T.J. (1966) The t-curve of multimolecular $\mathrm{N}_{2}$ adsorption. Journal of Colloid and Interface Science, 21, 405-414.

Delon, J.F. and Dellyes, R. (1967) Calcul du spectre de porosité des minéraux phylliteux. Comptes Rendus Académie des Sciences, Série D, 1661-1664.

Desprairies, A. (1983) Relation entre le parameter b des smectites et leur contenu en fer et magnesium. Application à l'étude des sediments. Clay Minerals, 18, 165-175.

Ewell, R.H. and Insley, H.V. (1935) Hydrothermal synthesis of kaolinite, dickite, beidellite and nontronite. Journal of Research of the National Bureau of Standards, 15, $173-186$
Farmer, V.C., editor (1974) The Infrared spectra of Minerals. Monograph 4, Mineralogical Society, London.

Fialips, C.I., Huo, D., Yan, L., Wu, J., and Stucki, J.W. (2002) Effect of Fe oxidation state on the IR spectra of Garfield nontronite. American Mineralogist, 87, 630-641.

Frost, R.L., Kloprogge, J.T., and Ding, A. (2002) Near-infrared spectroscopic study of nontronites and ferruginous smectite. Spectrochimica Acta, 58, 1657-1668.

Galhano, C., Rocha, F., and Gomes, C. (1999) Geostatistical analysis of the influence of textural, mineralogical and geochemical parameters on the geotechnical behaviour of the "Argilas de Aveiro" formation (Portugal). Clay Minerals, 34, 109-116.

Gates, W.P. (2005) Infrared spectroscopy and the chemistry of dioctahedral smectites. Pp. 125-168 in: The Application of Vibrational Spectroscopy to Clay Minerals and Layered Double Hydroxides (J.T. Kloprogge, editor). CMS Workshop Lecture Series, 13, The Clay Minerals Society, Aurora, Colorado, USA.

Goodman, B.A., Russel, J.D., and Fraser, A.R. (1976) A Mössbaauer and IR spectroscopic study of the structure of nontronite. Clays and Clay Minerals, 24, 53-59.

Greene-Kelly, R. (1953a) The identification of montmorillonoids in clays. Journal of Soil Science, 4, 232-237.

Greene-Kelly, R. (1953b) Irreversible dehydration in montmorillonite. Part II. Clay Minerals Bulletin, 1, 52-56.

Greene-Kelly, R. (1955) Dehydration of montmorillonite minerals. Mineralogical Magazine, 30, 604-615.

Hofmann, V.U. and Klemen, R. (1950) Verlust der Austauschfahigkeit von Lithiumionen an Bentonit durch Erhitzung. Zeitschrift für Anorganische Chemie, 262, 95-99.

Holtzapffel, T. (1985) Les minéraux argileux: préparation, analyse diffractométrique et détermination. Société Géologique du Nord, 12, 15-43.

Isphording, W.C (1975) Primary nontronite from the Venezuelan Guyana. American Mineralogist, 60, 840-848.

Jada, A., Debih, H., and Khodja, M. (2006) Montmorillonite surface properties modifications by asphaltenes adsorption. Journal of Petroleum Science and Engineering, 52, $305-316$.

Kloprogge, J.T (2006) Spectroscopic studies of synthetic and natural beidellites: A review. Applied Clay Science, 31, $165-179$.

Kloprogge, J.T., Komarneni, S., and Amonette, J.E. (1999a) Synthesis of smectite clay minerals: a critical review. Clays and Clay Minerals, 47, 529-554.

Kloprogge, J.T., Komarneni, S., Yanagisawa, K., Fry, R., and Frost, L. (1999b) Infrared Emission Spectroscopic study of the dehydroxylation via surface silanol groups of synthetic and natural beidellite. Journal of Colloid and Interface Science, 212, 562-569.

Komarneni, S., Fyfe, C.A., and Kennedy, G.J. (1986a) Detection of nonequivalent $\mathrm{Si}$ sites in sepiolite and palygorskite by solid-state 29 Si Magic-Angle SpiningNuclear magnetic resonance. Clays and Clay Minerals, 34, 99-102.

Komarneni, S., Fyfe, C.A., Kennedy, G., and Strobl, H. (1986b) Characterization of synthetic and naturally occurring clays by $27 \mathrm{Al}$ and 29 Si Magic-Angle Spinning NMR spectroscopy. Journal of the American Ceramics Society, 69, C. $45-$ C.47.

Lagaly, G., Ogawa, M., and Dékány, I. (2006) Clay mineral interactions. Pp. 309-377 in: Handbook of Clay Science (F. Bergaya, B.K.G. Theng, and G. Lagaly, editors). Developments in Clay Science, 1. Elsevier, Amsterdam.

Letaïef, S., Martín-Luengo, M.A., Aranda, P., and RuizHitzky, E. (2006) A colloidal route for delamination of layered solids: novel porous-clay nanocomposites. Advanced Functional Materials, 16, 401-409. 
Madejová, J. (2003) FTIR techniques in clay mineral studies. Vibrational Spectroscopy, 31, 1-10.

Madejová, J., Pentrák, M., Pálková, H., and Komadel. P. (2009) Near-infrared spectroscopy: A powerful tool in studies of acid-treated clay minerals. Vibrational Spectroscopy, 49, 211-218.

Malla, P.B. and Douglas, L.A. (1987) Problems in identification of montmorillonite and beidellite. Clays and Clay Minerals, 35, 232-236.

Mantin, I. and Glaeser, R. (1960) Fixation des ions cobalt hexamine par les montmorillonites acides. Bulletin $d u$ Groupe Français des Argiles, 50, 83-88.

Mehra, O.P. and Jackson, M.L. (1956) Iron oxide removal from soils and clays by a dithionide-citrate system buffered with sodium bicarbonate. Seventh National Conference on Clays and Clay Minerals, 317-327.

Mermut, A.R and Lagaly, G. (2001) Baseline studies of the Clay Minerals Society source clays: layer-charge determination and characteristics of those minerals containing 2:1 layers. Clays and Clay Minerals, 49, 393-397.

Nadeau, P.H., Farmer, V.C., McHardy, W.J., and Bain, D.C. (1985) Compositional variations of the Unterrupsroth beidellite. American Mineralogist, 70, 1004-1010.

Paquet, H. (1970) Evolution geodynamique des mineraux argileux dans les alterations et les sols des pays mediterraneans a saisons contrastees. Memoires Service Carte Geologique Alsace Lorraine, 30, 1-210.

Parthasarathy, G., Choudary, B.M., Sreedhar, B., Kunwar, A.C., and Srinivasan, R. (2003) Ferrous saponite from the Deccan Trap, India, and its application in adsorption and reduction of hexavalent chromium. American Mineralogist, 88, 1983-1988.

Pevear, D.R. and Mumpton, F.A. (1989) Quantitative Mineral Analysis of Clays. The Clay Minerals Society, Evergreen, Colorado, USA, $171 \mathrm{pp}$.

Plee, D.G.L. and Fripiat, J.J. (1987) Pillaring processes of smectites with and without tetrahedral substitutions. Clays and Clay Minerals, 35, 81-88.

Post, J.L. and Borer, L. (2002) Physical properties of selected illites, beidellites and mixed-layer illite-beidellites from southwestern Idaho, and their infrared spectra. Applied Clay Science, 22, 77-91.

Post, J.L. and Noble, P.L. (1993) The near-infrared combination band frequencies of dioctahedral smectites, micas, and illites. Clays and Clay Minerals, 41, 639-644.

Post, J.L., Cupp, B.L., and Madsen, F.T. (1997) Beidellite and associated clays from the DeLamar Mine and Florida mountain area, Idaho. Clays and Clay Minerals, 45, $240-250$.
Rautureau, M., Caillère, S., and Hénin, S. (2004) Les Argiles, seconde édition. Editions Septima. Paris, $98 \mathrm{pp}$.

Rhouta, B., Kaddami, H., Elbarqy, J., Amjoud, M., Daoudi, L., Maury, F., Senocq, F., Maazouz, A., and Gerard, J.-F. (2008) Elucidating the crystal-chemistry of Jbel Rhassoul stevensite (Morocco) by advanced analytical techniques. Clay Minerals, 43, 393-404.

Ruiz-Hitzky, E., Aranda, P., and Serratosa, J.M. (2004) Clayorganic interactions: Organoclay complexes and polymerclay nanocomposites. Pp. 91-154 in: Handbook of Layered Materials (S.M. Auerbach, K.A. Carrado, and P.K. Dutta, editors). Marcel Dekker, Inc., New York.

Russel, J.D., Farmer, V.C., and Velde, B. (1970) Replacement of $\mathrm{OH}$ by $\mathrm{OD}$ in layer silicates and identification of the vibrations of these groups in infrared spectra. Mineralogical Magazine, 37, 869-879.

Schutz, A., Stone, W.E.E., Poncelet, G., and Fripiat, J.J. (1987) Preparation and characterisation of bidimensional zeolitic structures obtained from synthetic beidellite and hydroxylaluminum solutions. Clays and Clay Minerals, 35, 251-261.

Sing, K.S.W., Everett, D.H., Haul, R.A.W., Moscou, L., Pierotti, R., Rouquérol, J., and Siemieniewska, T. (1985) Reporting physisorption data for gas/solid systems with special reference to the determination of surface area and porosity. Pure and Applied Chemistry, 57, 603-619.

Stamm, R. and Thein, J. (1982) Sedimentation in the Atlas Gulf III: Turonian carbonates. Pp. 459-475 in: Geology of the Northwest African Continental Margin. Springer-Verlag, Berlin.

Thorez, J. (1976) Practical Identification of Clay Minerals. A Handbook for Teachers and Students in Clay Mineralogy (G. Lelotte, editor). Dison, Belgium.

Trauth, N. (1977) Argiles évaporitiques dans la sedimentation carbonate continentale et épicocontinentale tertiaires: Bassins de Paris, de Mormoiron et de Salinelles (France) et du Jbel Ghassoul (Maroc). Sciences Géologiques, Mémoires, 49, 195 pp.

Velde, B. (1995) Origin and Mineralogy of Clays: Clays and the Environment. Springer-Verlag, Berlin, Heidelberg, New York, $334 \mathrm{pp}$.

Weir, A.H. and Greene-Kelly, R. (1962) Beidellite. American Mineralogist, 47, 137-146.

Woessner, D.E. (1989) Characterization of clay minerals by ${ }^{27} \mathrm{Al}$ nuclear magnetic resonance spectroscopy. American Mineralogist, 74, 203-215.

(Received 9 September 2011; revised 30 May 2012; Ms. 588; A.E. T. Kogure) 